\title{
HISTORICAL MEMORY OF TATARS IN BULGARIA AND IN LITHUANIA - COMPARATIVE ASPECTS ${ }^{1}$
}

\author{
Veneta Yankova \\ Eötvös Loránd University (ELTE), Budapest, Hungary \\ e-mail:veneta_yankova@abv.bg
}

\begin{abstract}
The article is part of a larger study from which only some theses are presented here. The theoretical framework of the study is grounded in the concept of historical memory which is understood as a generalised image of the knowledge of the past, made up of many interacting ideas conceived as information, functions and processes of representation, constructiveness, updating. The historical memories of the Tatars in Bulgaria and in Lithuania are being recognised as an important component of the particular historical heritage of the respective regions. The present analysis identifies their contribution in building the regional cultural specificity since the former migrants not only incorporated themselves into the host society, but they also left their mark in the local memory. In this way, they helped change the cultural landscape by incorporating themselves into the cultural specificity of the given space. That is why the studied areas could be thought of as historically formed cultural regions and, more precisely, multicultural regions in whose construction the historical memory of/for the other is involved.
\end{abstract}

Keywords: historical memory, Tatars in Bulgaria, Tatars in Lithuania 


\section{Introduction}

Tatar communities on the Balkans, in Poland and in the Baltic countries represent historical diasporas today. Their distinctive culture and participation in the history of the inhabited regions helped create a cultural specificity of their own. These communities are characterised by the so-called diaspora identity (Williams 2001), which was formed under the influence of intellectual elites and cultural and educational institutions, as well as by a corresponding diaspora historical memory with its indicative image and symbolic manifestations. The notion of the Crimea as a land of origin occupies an important place in the historical memory of the Tatars not only in Bulgaria but also in the Baltic region. But while the migration from the Crimea is still a living ancestral memory for the Tatars in Bulgaria, the Tatars elsewhere in Europe have not preserved such a memory. It is important to note that in the notions of present-day Tatars there is a vast symbolic space stretching from the Crimean peninsula through the Black Sea (Dobroudzha) and to the Baltic region, which is full of the toposes of the Tatar past. As Harry Norris sums it up: "The regions from the Baltic to the Black Sea shape their identities" (Norris 2009: 145-146).

This determines the comparative aspects of the present exposition. The article is part of a larger study from which only some theses are presented here. The theoretical framework of the study is grounded in the concept of historical memory which is understood as a generalised image of the knowledge of the past, made up of many interacting ideas conceived as information, functions and processes of representation, constructiveness, updating, etc. (...).

\section{Alternative Historical Memory (Crimean Tatars from Northeastern Bulgaria)}

Crimean Tatars in Northeastern Bulgaria are part of the demographic legacy of the Ottoman epoch on the Balkans. Until recently the study of the history of the community was carried out mainly in the context of the idea of a Bulgarian nation, an idea which was being built in the $19^{\text {th }}$ century and in relation to the Bulgarian national narrative, whereupon the approach of excluding those who are foreign was followed - aliens, colonised, Muslims. The concept of historical memory allows for the construction of a more real and demythologised Tatar image as well as for rethinking the Tatar past on the Balkans and 
its inclusion as an important part of the historical heritage of certain regions in Northeastern Bulgaria. The memory of Crimean Tatars is viewed as a case of alternative historical memory, which in some aspects complements the official historiography and opposes the national narrative. The exposition is directed towards the bringing to light two main ethno-deterministic approaches to the past: one of them was created by observers who were external to the community (European travellers, researchers, etc.), an approach represented by more documentary evidence (1.) and the other approach, the so-called ethnohistory, which presents the people's own historical narrative about events of the past (2.).

(1.) The testimonies of the others are introduced through the presentation of the images of the Tatars in the Bulgarian national narrative in the $19^{\text {th }}$ century. The analysis of folklore texts and literary works from the Bulgarian Revival period (until the end of the 1870s) outlines the Tatar topic in the collective memory of Bulgarians. It is found that the heterogeneous Tatar images are included in the paradigm of the emerging national narrative as variants of the unambiguous, unified and stereotyped image of the ravager. The denomination "Tatars" in the context of Bulgarian folk songs is used as a generalisation of a hostile alien. For the purposes of the national narrative, oral traditions reproduce mythologemes and narrative models which form a folkloric-mythological matrix in the understanding of the foreign. Such mythological images are also spread in the writings of the late $18^{\text {th }}$ and $19^{\text {th }}$ centuries in support of the Bulgarian "great narrative" which legitimised the ideological project for the creation of the nation. Similar ethnic stereotypes, formed according to models of folklore culture, prevail in historiographic, publicistic and literary texts from the National Revival period.

Migration movements from the middle of the $19^{\text {th }}$ century and the migration of the Tatars from the Crimea to the Balkans are recorded in the travel notes of some European observers of the relationship between the Ottoman Empire and the Russian State. The case of the French physician Camille Allard (18..-1864) who travelled through Dobrudzha in the autumn of 1855 - just about the time of the Crimean War (1853-1856) - and recorded his direct impressions of Dobrudzha Tatars is indicative (Allard 1864). His notes contain important details about the Crimean migrants in the Constanta (Köstence) region and the Tatar village of Karaköy in an early stage of their settlement in this region of the Balkans. The encounters of the French physician with the otherness in its Tartar manifestations are marked by signs of ethnocentrism and stereotypical 
notions. In his narrative there is no distancing glance towards the physician's own culture but the immediate interaction between him and the Tatars and the gradual process of familiarizing himself with them give rise to understanding and significantly weaken the original prejudices. The records reflect important information about Tatar immigrants from the Crimea as a result of direct observations during their active migrations to the Balkans. Valuable information of immediate character was preserved about the processes of settlement and adaptation to the new environment, the social and religious organization, social differentiation, crafts, lifestyle and mentality of the migrants, their cultural specificity and their differentiation from the local people. The AustroHungarian cartographer Felix Kanitz, who travelled through Danube Bulgaria in 1860-1879 was also a direct witness of Tatar colonisation on the Balkans. The images of Tatar migrations during the $19^{\text {th }}$ century, preserved by him, reflect a more objective and more realistic view of the reality of the migration in its complexity, proneness to conflicts, contradiction and political root causes. But a number of historical and ethnographic texts published after the Liberation (Konstantin Jireček, Georgi Dimitrov, Yov Titorov) demonstrate the persistence of stereotyped notions about Tatars and their past.

The observations of others are supplemented by data from Bulgarian periodicals from the time of the migrations ("Tsarigradski Vestnik" (Constantinople newspaper), "Dunavski Lebed" (Danubian Swan) and "Bulgaria", etc.) as well as from the local oral history. The cultural contact with Tatars during the $19^{\text {th }}$ century begot extremity - in the ethnocultural dimensions of the notion - for the European participants in the contact. Even for those who had immediate impressions and longer contact with the migrants, it was almost impossible to break free from the paradigm of their own culture, also the national and European stereotypes and prejudices towards the Tatars. For a long time, the notions about Tatars remained in the farthest register of otherness associated with the foreign, hostile and dangerous. Such an approach uncritically mythologised the public image of the Tatar, and turned out to be quite resilient both in the most largely spread notions of society and in historiography. From the mid- $19^{\text {th }}$ century the perceptions about the Crimean immigrants began to be grasped in their everyday human manifestations thanks to the experience of direct communication. An understanding of the Tatar contribution to the history of the region of Northeastern Bulgaria and Dobrudzha was gradually built. Nevertheless, popular views continued to reproduce stereotypical images and preconceptions about the colonised. 


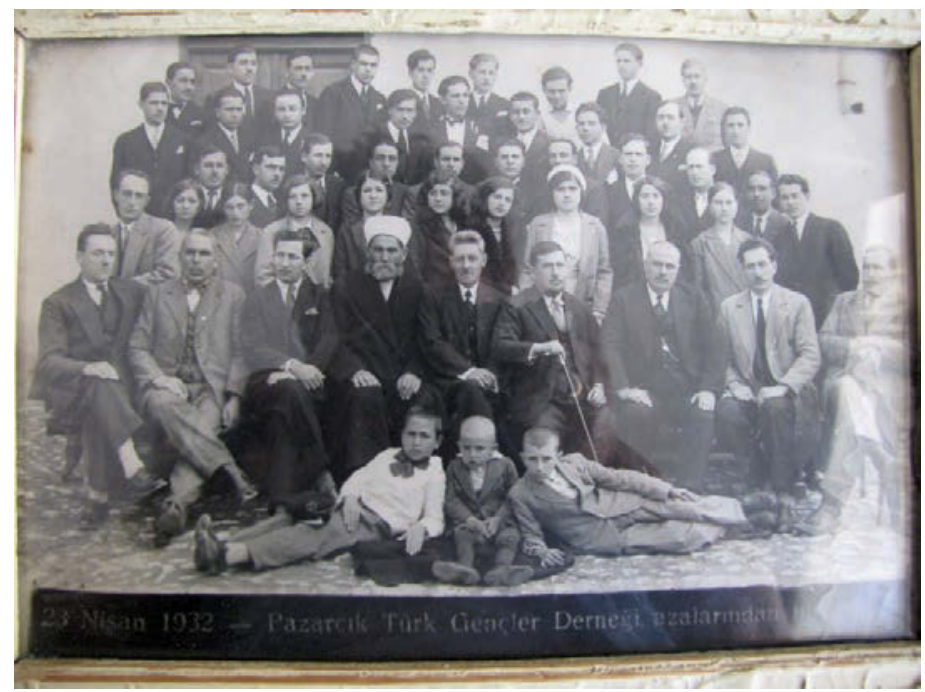

Figure 1. Tatars from Bulgaria (Dobrich, 1932). Picture from "Mevlyana club" in Dobrich. Photo by V. Yankova.

(2.) The personal story of the past reflects the points of view of the community and its members regarding events and personalities of the past and includes elements, images and notions that often remain invisible and incomprehensible to the external observer. This is an unrecorded, unpreserved, fragmentary memory, in whose functioning and transmission models of traditional folklore language prevail. It is limited to the recent past and family memory and reflects detailed information about the past of the community. Such a historical memory is a foundation for the ethnohistory of the community.

Due to the time gap and the growing shortage of "memory keepers", the migration of the Tatar ancestors from the Crimea is a story which is gradually being effaced from the preserved oral history. This story is scattered in fragmentary family memories of the migrant ancestors. The most general reconstruction of the oral history of the migration to the Balkans demonstrates that its narrative follows the trajectories of migration by crossing spaces and cultures and marking its counterpoints: the starting point from where the migrants leave and the place of settlement in the new environment. The oral history of the Tatar migrations to the Balkans is shaped as a distant fragmen- 
tary narrative told by an integrated historical diaspora community that seeks to preserve its ethnocultural specifics. In the family memories the facts and events of the history of the migration are summarised in dramatic stories of escape from violence and war. The immigrant past of the community has been reduced to many family stories that reflect a generational attempt to survive and adapt. And since the memory of the descendants reconstructs the debris of what happened in times gone, heroic and legendary notions are added to the images of the migrant ancestors and these notions determine the mythographic potential of the family stories. They are supported by the sacralised values of family relics and by the emblematic notions of Tatarness - the land of origin, the Crimean, and the Tatar house. The narratives told today about the migrations to the Balkans are part of the great tale of Tatar integration in the host environment and of the Tatars' own contribution to its cultural and historical heritage. Today the lack of historical knowledge and the fragmentation of Tatar family memory is compensated by the self-reflection of contemporary academic and popular science publications on Tatar issues. Such a critical and devised notion of the past carries the message of a different story, a peculiar alternative to official historiography.



Figure 2. Old Tatar house, Onogur village. Photo by V. Yankova. 
The oral history of the Dzhamadin family is indicative of the complex processes of adaptation of the migrants from the Crimean Peninsula to a different social and cultural environment on the Balkans. It constructs a generalised notion of real-world historical events which is achieved by the use of selectivity, reconstruction and "legendarising" of facts and events. Affirmed via the exemplar of the ancestors, the "own" in the minds of the family descendants is harmonious and somewhat idealised. And this is a potential element of a future family mythography. The memories of Ridvan Kyashif from the village of Onogur, Dobrich region, are a personal testimony of family history and family memory. According to their message, the Tatar past is an inalienable part of the past of the village and of the region; the Tatars are inscribed in the microhistory of the settlement and have left their traces in the local memory. The notion of the Kyashif family is highlighted as part of the idea of Tatarness, which is distinguished from the Turkish ethnic culture and outlined by the primordial markers of the "own" such as "language, blood and soil". The images of the past are reduced to the family memory stretching within the compassable bounds of time. It is conceived as an inheritance that must be preserved and transmitted between generations as a guarantee for the family's durability. An indicative trend registered among the Tatars in Bulgaria today is the construction of a personal myth and an aristocratic genealogy. Such amateurish surveys have been created to compensate for the awareness of the insufficient knowledge about the past and the need for a dignified memory built via the constructs of the Tatars' own glorious history and the family myth. The anthropological approach to such cases assesses them in a more adequate way as an opportunity to correct and complement the official historical narrative by creating a "history of their own" in order to achieve a richer and more multifaceted idea of the past. On the basis of the analysed material, the main images of the past are outlined, a past which is represented in fragmentary and generalised dimensions, covering the chronology of the recent past.

The diaspora memory highlights the role of the progenitor who came from the Crimea and/or is a unit of a constructed aristocratic genealogy but who is necessarily transformed into a symbolic capital for the family. Such a concept of the past is conceived as part of the microhistory of the individual settlements and the historical heritage of the entire region. The prominent family testimonies that belong to the popular knowledge of the Tatars' past in Bulgarian Dobrudzha are fragments of the Tatars' ethnohistory, which, despi- 
te its multifaceted and sometimes controversial nature, can be considered as a kind of corrective for the ethnocentric national history. These are examples of alternative memories that complement or even compete with the national memory that dominates in the official historiography by asserting a pluralistic point of view of the events of the past.

Summary: In the clarification of the Tatar participation in the history of the Balkans in the popular perceptions and in historiography until recently it is necessary to bear in mind the significant role of the images and the notions of this past: the Tatar narrative was formed in close correlation with and in opposition to the Bulgarian national narrative and was also influenced by stereotypes and prejudices widespread in the European cultural space. But although the European travellers and researchers perceived the cultural contacts with the Crimean migrants as signs of the hostile alien, the ethnohistory of the Tatars created critical and devised notions that carry the message of a different narrative and this ethnohistory is perceived as a kind of corrective for the ethnocentric national history.

\section{Heroic Historical Memory. Tatars in Lithuania}

The empirical case of the European Tatars - Tatars in Poland, Lithuania and Belarus, provides an opportunity for the observation and analysis of the heroic historical memory.

(1). The Islamic culture of the Tatars in Lithuania has a religious memory of its own, sacred toposes (mosques, cemeteries, local places of worship), a corresponding legendary topography, and it manifests itself in characteristic (ritual, oral and written) forms. This religious cultural memory is governed by the authority of the ancestors and outlines the trajectories of the correlation with the past according to the canons of the patriarchal world, from the myth to the legend and the family memory. The memory transmitted via verbal communication from one generation to the other functions on the boundary between remembering and forgetting, the personal memory and the ancestors' narratives of the past. It is concentrated in toponyms - verbal signs of places that no longer exist (settlements, lands, cemeteries) related with the traces left by the Tatars. The religious literature of the Lithuanian Tatars represents a unique cultural phenomenon since it is based on several local languages 
(Polish and Belarusian) while preserving some Arabic, Ottoman and TurkicTatar language elements. During the centuries-long existence of Lithuanian Tatars in a different environment they preserved the long-lasting memory of their specific culture with religious codes of its own. In the cultural memory of the community, Islam is perceived as a fundamental value in which the members of the diaspora seek and find their essence. In the collective notions, Islam is conceived as a supreme value on the maintenance of which the existence of Tatarness depends. Tatar Muslim tradition and Islam, called "the religion of the ancestors", are also perceived as an inheritance from the previous generations. Through them a "sense of the past" is being maintained which is perceived as knowledge of the past, respect and attachment to the "legacy of the ancestors" and an effort to preserve and continue it or follow suit. The conception of Islam as a "religion of the ancestors" is a guarantee for vitality, durability and continuity of the community over time. Such an ethno-confessional belief in religion also motivates the demarcation between Lithuanian Tatars and the "new" Muslims in the region.

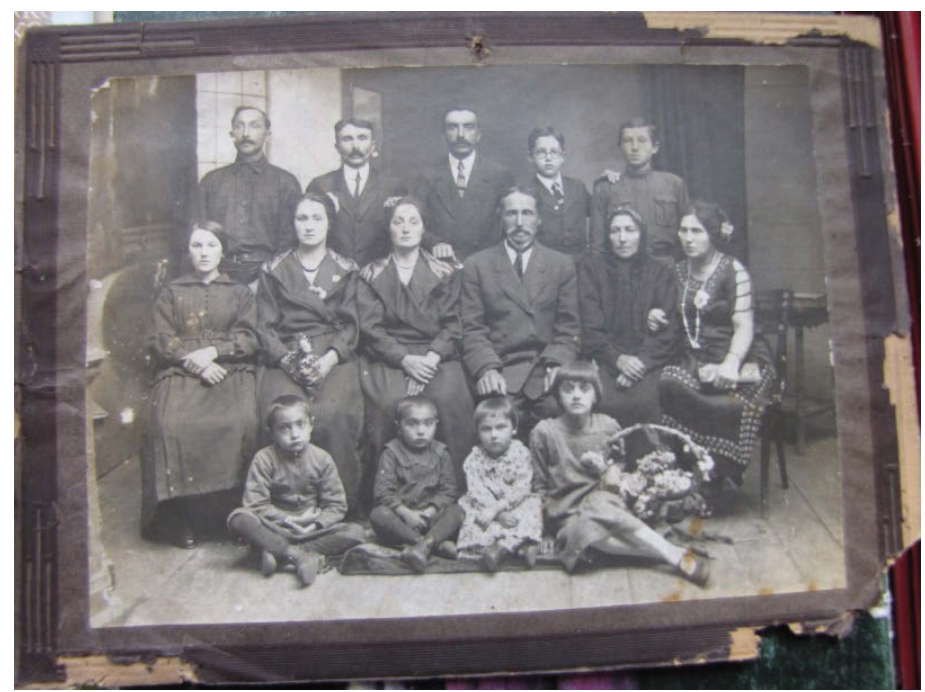

Figure 3. Tatars from Lithuania. Picture from Lithuanian Tatar household museum, Subartonys. Photo by V. Yankova. 
In the generalised notions of the macro-society, the perception of the exceptional contribution of local Tatars to the national histories of the peoples of the region dominates. And, according to the Tatars' opinion of themselves, they are "faithful to their military duty and oath", "faithful to the land that has accepted them as a people of its own".

(2). The role of historiography is also important in the social construction of memory. From the mid- $19^{\text {th }}$ century until the mid- $20^{\text {th }}$ century fundamental historiographic texts were published which formed important trends in the construction and perception of Tatars today. The period which lasted nearly a hundred years and during which Tatar ethnohistory was formed - with the idea of rehabilitation as its main message - led to the construction of the concept of this past as "heroic annals". Driven by the energy of the Tatar intellectual elite of the 1920s and 1930s, the concept of the ancestors' history and their heroic martial past became a factor for ethnic mobilisation and consolidation for the whole Tatar community. The widely popularised historiographic works which were created generated prestigious heroic models and positive messages that strengthened the Tatars' self-identification. The most highly developed, documented and publicly presented to date is the military history of European Muslims with its inscription in the heroic past of the region. Through the authority of professional historiography during the 1920s and 1930s a powerful process of "production of images" and of myth-making was set in motion, a process which was interrupted in the mid- $20^{\text {th }}$ century by the events of the Second World War and was later resumed in new dimensions in the changed socio-political context of the 1990s. Tatar ethnohistography rejected in a wellgrounded way the prejudices existing at those times and formed another image of the Tatar - a reconstructed, restored, enriched, multifaceted and at the same time invented since its purpose was to fundamentally change public attitudes. The new Tatar image was shaped under the influence of the ideas dominating during the interwar period as part of the national mythomotorics, the ethnomobilising ideology and rhetoric of its time. At the same time, the mythology of the Tatar migration to this part of Europe and the genesis of the Lithuanian Tatars' community were validated.

In the context of such a historiographic strategy, a prestigious notion of the Tatar as a warrior, a warlord and a nobleman was validated. This was an image which was historically documented and "partly invented" in the family legends, an image related to the knightly virtues of the ancestors from the Middle Ages 
and to the universal nostalgia for lost origins. The Tatar narrative was shaped as heroic and directly related not only to the history of the Grand Duchy of Lithuania but also to its successors. Tatar participation in the history of the region is perceived as a vital national resource and a sustainable topos of social activity. As a result of in-depth research, the perception of the Tatar past is affirmed as a part of the local past, the ethnic memory is experienced as a common, shared memory, and the Tatar narrative is integrated into the national narrative. The Tatar story of the past is constructed not as an alternative, but according to the dominant "great narrative", whose main message regulates the durability and cohesion of the nation over time. The semantics of such a heroic and dignified perception of Tatar history should become a rationale for the national unity in the present and a guarantee of its future.

The memory of words - legendary, narrated and recorded, factological and "partly invented", passes a thread between the monolithic and unambiguous character of the legendary narrative, the genealogical legends and the kaleidoscopic character of the oral history and the tangibility of what once was reflected in the life stories. The mythology of the Tatar settlement and the biographical testimonies of crises survived by the community mark counterpoints in the historical memory of the European Tatars. The stories of the beginning in the legendary history of the Tatars follow the invariant model of the mythology of the migrations representing the movement from the starting point to the end point of their settling down. Due to the remoteness in time of the Middle Ages, there is not enough data on migrations as a process, and the evidence of the space of the exodus is stored in generalising and symbolic forms. This lack of sufficient information is compensated by the stories about the settlement in the lands of the Grand Duchy of Lithuania, stories which have built a mythography which is still vital today. The mythology of the settlement is a heroic "story of kings and battles" and of great men in which history is shown as "a metaphor of mythical realities". In such a tale of the past, the role of Vytautas the Great (1392-1430) - an ancestor and hero - as well as of the ancestors who are perceived as noble and loyal warriors, is central. Toponyms, toponymic tales and etiological legends point to the local versions of this mythological text and outline the topography of the Tatar settlement in the area and the topographic variable traces in local memory. They construct a more complete and harmonious narrative about the genesis of the Tatar community in this territory. In its basic elements, Tatar mythography follows the trajectory of the national narrative in emphasising the heroic and dignified Tatar participation in it. ${ }^{2}$ 
Today genealogical studies among the Tatar population are an object of increased public interest including both professionals and amateurs, genealogies and family stamps are being reconstructed and the biographical memories pass on the motive of the prestigious aristocratic family background. However, this activity is not built only on a historical and documentary basis but also on an uncritical personal interpretation of the sources, invention of facts and events of the past. Such an approach originates in the popular understanding of special origin as an expression of social prestige, a reason for pride or some other social need. Such a need for elitism/belonging to a privileged class and for distinction can also be seen as a reaction against the unification, a reaction which motivates the fashionable world trend of taking interest in genealogy nowadays.

(3). The 1990s marked the beginning of the newest period in the history of the European Tatars which is characterised by the revived interest in their own past, the reconsideration of the cultural and historical heritage, the introduction of new facts and documents into scientific circulation and their popularisation through the media and the global network. Such an understanding of the past - as a value - and the need to "remember one's roots" in the construction of the present have triggered numerous commemorative practices related to emblematic Tatar toposes. The driving force behind this process is the modern Tatar intelligentsia which perceives itself as a kind of a continuator in the new conditions of the work of the figures from the times of the Tatar revival. At the boundary between two millennia, the policies of memory and the saturation of the public space with the loci of Tatar history and the creation of new "places of memory", as well as their revival through commemorative activities, have important functions. The periodic repetition of commemorations, celebrations and holidays ritualises the memory and revives the images of the past. The recalling via the act of repetition is directed against forgetting, toward the "memory as a duty" and is an important precondition for cohesion within the community. There is also a public recognition and legitimation of the Tatars' merits as an ethno-confessional minority for the building of a specific ethnocultural image of the region and for the common past shared with the host environment. This helps maintain a positive image of the whole Tatar community. The policies of Tatar periodicals are characterised by the view of the importance of history and the need for a more diverse understanding of the Tatar past in the region. 
Historical Memory of Tatars in Bulgaria and in Lithuania - Comparative Aspects
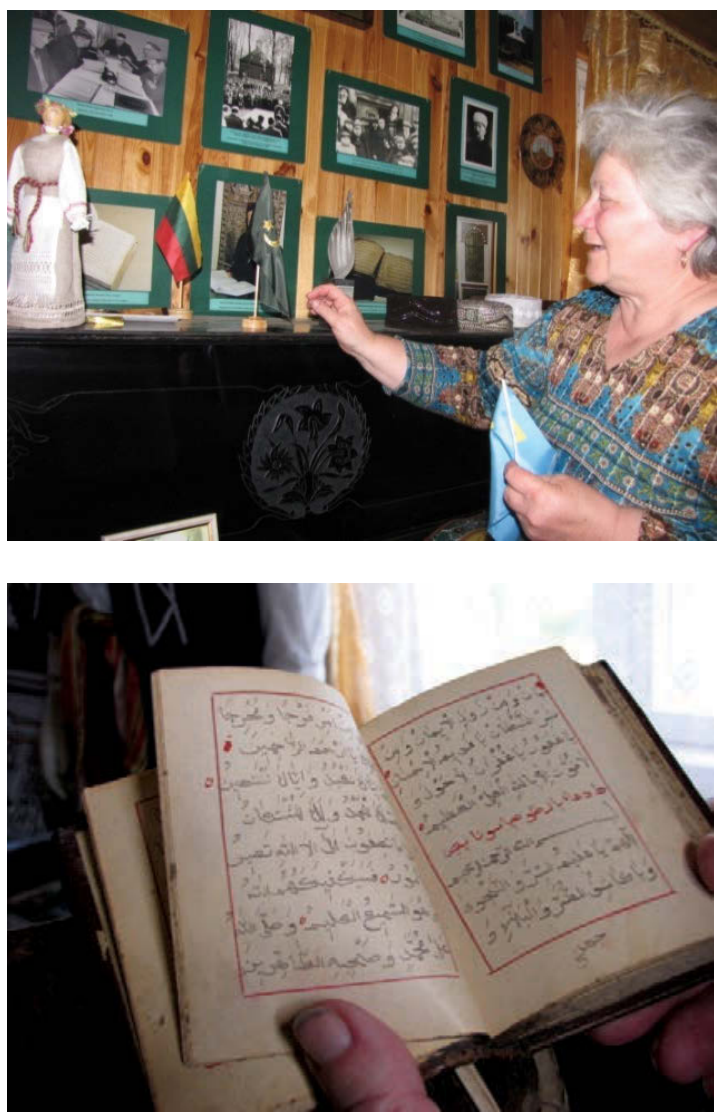

Figures 4-5. Exposition and book in Arabic alphabet from Lithuanian Tatar household museum, Subartonys. Photos by V. Yankova.

The popular historical narrative in the aforementioned periodicals coexists with a complementary idea of events and personalities from medieval Tatar history and from the Islamic world. Thus the chronicle of the European Tatars is shaped at the same time as a part of the local/regional past and the "great" history of the Tatars in the world. 
Summary: During the period which lasted for nearly a hundred years the ethnohistory of Tatars in Lithuania was formed and the idea of their heroic and dignified past was constructed. The historiographic works generated prestigious exemplars and positive messages that strengthened Tatar self-identification. Such an attitude towards the past plays an important consolidating role for the Tatar community and supports the policies of recognition by the macrosociety. In its basic elements, Tatar mythography follows the trajectory of the national historical memory by becoming a rationale for national unity in the present and a guarantee of its future. The greater part of the historical memory of Tatars in Lithuania is based on mediated, learnt, retransferred experience and knowledge, acquired via different media of memory, and not via the direct life experience and sensory experience of the individuals/community that keep the memory. This fact determines the intensity of the construction of the ideas of the Tatar past to a great extent today. Such a heroic historical memory of the past of the European Tatars makes part of the national patrimonium, it explains the specificity of the historical heritage and the cultural specificity in this European region.

\section{Conclusions}

The idea of the national plays an important role in shaping the presented historical memories. Through its all-encompassing and normative character, the national historical memory leaves its mark both on the "little narrative" of ethnohistory and on the "history of the regions". The particular national and community elites offer the symbolic construction of different models of collective identity for the focus groups being studied. This is why the types of historical memory that have been examined mark different correlations to the national mythology and the national narrative: they are their alternative (a complement and/or counterpoint), an episode of theirs or their projection (a micromodel). This is also due to the specificity of the historical and cultural contexts in which the separate memories are formed and/or registered - in active processes of national affirmation, national and regional/territorial consolidation, and others.

The historical memories of the Tatars in Bulgaria and in Lithuania are being recognised as an important component of the particular historical heritage 
of the respective regions. The present analysis identifies their contribution in building the regional cultural specificity since the former migrants not only incorporated themselves into the host society, but they also left their mark in the local memory. In this way, they helped change the cultural landscape by incorporating themselves into the cultural specificity of the given space. That is why the studied areas could be thought of as historically formed cultural regions and, more precisely, multicultural regions in whose construction the historical memory of/for the other is involved.

\section{Notes}

1 The article is part of a monograph in preparation titled "Historical memory and images of the past. Based on examples from Bulgaria, Hungary, Poland and Lithuania". 2 А. Мухлинский "Исследование о происхождении и состоянии литовских татар" (1857); "O muślimach litewskich. Z notat i przekładów litewskiego tatara Macieja Tuhana-Baranowskiego" (1896); Talko-Hryncewicz, J. "Muślimowie czyli tak zwani Tatarzy litewscy". Kraków (1924); St. Dziedulewicz "Herbarz rodzin tatarskich w Polsce" (1929); St. Kryczyński “Tatarzy litewscy. Próba monografii historyczno-etnograficznej. Rocznik Tataryw Polskich, 3" (1938) and others.

\section{References}

Allard, Camill 1864. Souvenirs d'Orient. La Bulgarie orientale. Paris: Adrien Le Clere et Cie, C. Dillet.

Dziadulewicz, Stanislav 1929. Herbarz rodzin tatarskich $w$ Polsce [Herald of Tatar Families in Poland]. Wilno: Dziadulewicz Stanisław.

Kryczyński, Stanislav 1938. Tatarzy litewscy. Próba monografii historycznoetnograficznej [Lithuanian Tatars: An Attempt at a Historical-Ethnographic Monograph]. Rocznik Tataryw Polskich 3.

Muchliński, Antoni 1857 = Мухлинский, Антон Осипович. Исследование о происхождении и состоянии литовских татар [Research of Origin and Composition of Lithuanian Tatars]. St.-Petersburg: O. Weimar.]

Norris, Harry 2009. Islam in the Baltic. Europe's Early Muslim Community. London New York: I. B.Tauris \& Co. Ltd.

Talko-Hryncewicz, Julijan 1924. Muślimowie czyli tak zwani Tatarzy litewscy [Muslims, or So-Called Lithuanian Tatars]. Kraków: Nakładem Księgarni Geograficznej, "Orbis". 
Veneta Yankova

Tuhan-Baranowski, Macej 1896. O muślimach litewskich. Z notat i przekładów litewskiego tatara Macieja Tuhana-Baranowskiego [Lithuanian Muslim Tatarians]. Warszawa: Gebetner-Wolff.

Williams, Brian 2001. The Crimean Tatars. The Diaspora Experience and the Forging of the Nation. Brill's Inner Asian Library, No. 2. Leiden - Boston: Brill. 